\title{
Implementasi Manajemen Bimbingan dan Konseling di MTs NU TBS Kudus
}

\author{
Muhammad Aqib Khusnul Bayan \\ Pascasarjana IAIN Kudus, Jawa Tengah, Indonesia \\ aliftlupin29@gmail.com
}

\begin{abstract}
Abstrak
Penelitian ini bertujuan untuk mengetahui implementasi manajemen bimbingan dan konseling di MTs TBS Kudus. Metode dalam penelitian ini menggunakan metode deskriptif kualitatif dengan pendekatan studi kasus di MTs TBS Kudus. Data yang terkumpul kemudian dianalisis dengan teknik analisis data yang digunakan dalam penelitian ini adalah analisis deskriptif dilapangan model Miles and Huberman. Hasil penelitian menunjukan bahwa implementasi manajemen bimbingan konseling di MTs TBS Kudus telah berjalan dengan baik. Tahap perencanaan program adalah dengan analisis kebutuhan dan masalah siswa, analisis kondisi sekolah, penentuan tujuan, memahami dan menentukan materi, penentuan waktu dan tempat, penentuan fasilitas dan perencanaan anggaran. Tahap pengorganisasian dilaksanakan dengan memilih konselor yang kompeten. Tahap pelaksanaan bimbingan dan konseling di MTs TBS Kudus dengan melaksanakan layanan konseling sesuai dengan SOP dilengkapi kegiatan pendukung. Tahap evaluasi program BK dengan mengevaluasi program-program kemudian diperbaiki kembali.
\end{abstract}

Kata kunci: Implementasi, Manajemen Bimbingan Konseling, MTs TBS Kudus 


\begin{abstract}
Implementation of Guidance and Counseling Management at MTs NU TBS Kudus. This study aims to determine the implementation of guidance and counseling management at MTs TBS Kudus. The method in this study uses a qualitative descriptive method with a case study approach at MTs TBS Kudus. The collected data was then analyzed by the data analysis technique used in this study is a descriptive analysis in the field of the Miles and Huberman model. The results showed that the implementation of the management of counseling guidance at MTs TBS Kudus has been going well. The program planning stage is by analyzing student needs and problems, analyzing school conditions, determining goals, understanding and determining materials, determining time and place, determining facilities and planning budgets. The organizing stage is carried out by selecting a competent counselor. The stage of implementing guidance and counseling at MTs TBS Kudus by carrying out counseling services in accordance with SOP equipped with supporting activities. The evaluation stage of the BK program is by evaluating programs and then improving them again.
\end{abstract}

Keywords: Implementation, Counseling Guidance Management, MTs TBS Kudus

\title{
A. Pendahuluan
}

Bimbingan konseling merupakan salah satu program yang terdapat pada dunia pendidikan yang membantu para peserta didik/siswa dalam mengatasi problem-problem yang sedang dihadapinya. Sebagai mana yang tertera dalam P-4 sebanyak 36 butir bagi bangsa Indonesia, Pancasila merupakan dasar negara, pandangan hidup, kepribadian bangsa dan ideologi nasional. Pancasila menuntut bangsa Indonesia mampu menunjukkan ciri-ciri kepribadiannya di tengah-tengah pergaulan saat ini dengan bangsa lain. Bimbingan disinilah sebagai bagian yang tak terpisahkan dari dunia pendidikan khususnya dalam mewujudkan siswa Pancasilais, karena seluruh kegiatan terutama bimbingan tak luput dari peran Pancasila.

Tujuan bimbingan dan konseling adalah untuk mengembangkan potensi pada individu seoptimal mungkin, sesuai dengan kemampuan agar bisa menyesuaikan diri dengan lingkungannya, baik lingkungan sekolah, keluarga maupun lingkungan masyarakat (Bastomi, 2020). Menurut Yusuf \& Nurihsan dalam Bastomi (2019) Proses Bimbingan dan Konseling di sekolah dapat berhasil apabila mempunyai tujuan yang jelas yang akan dicapainya. Bimbingan dan 
konseling bertujuan untuk membantu peserta didik agar dapat mencapai tujuantujuan perkembangannya yang meliputi aspek pribadi-sosial belajar (akademik) dan karir. Sedangkan tujuan bimbingan dan konseling Islam menurut Mubarok dalam Bastomi (2017) Secara singkat dapat dirumuskan sebagai berikut : (1) Tujuan umum Konseling Islam untuk membantu konseli agar dia memiliki pengetahuan tentang posisi dirinya dan memiliki keberanian mengambil keputusan, untuk melakukan suatu perbuatan yang dipandang baik, benar dan bermanfaat, untuk kehidupannya di dunia dan untuk kepentingan akhiratnya. (2) Tujuan khusus bimbingan konseling Islam adalah: (a) Untuk membantu konseli agar tidak menghadapi masalah. (b) Untuk membantu konseli mengatasi masalah yang sedang dihadapinya. (c) Untuk membantu konseli memelihara dan mengembangkan situasi dan kondisi yang baik atau yang telah baik agar tetap baik, sehingga tidak akan menjadi sumber masalah bagi dirinya dan orang lain. Guna mencapai tujuan bimbingan konseling sesuai yang diharapkan tentunya proses manajemen bimbingan dan konseling harus berjalan dengan sangat baik.

Siswa merupakan pemeran aktif sebagai warga sekolah yang membutuhkan bantuan karena masih berada dalam proses perkembangan dimana siswa mengalamai hambatan dan kesulitan dalam pemahaman diri sendiri dan juga lingkungannya. Oleh karena itu, disini lah peran layanan Bimbingan konseling sangat membantu dalam mengakomodir apa yang dibutuhkan siswa. Dalam proses perkembangan diri siswa tersebut, layanan Bimbingan konseling perkembangan merupakan layanan dasar yang responsifdan proaktif dalam bertujuan mengembangkan dan mendorong individu tersebut untuk berkembang secara optimal dan produktif.

Konselor dalam hal ini adalah guru BK dituntut dalam penyelenggaraan layanan Bimbingan dan Konseling yang professional, sudah tercatum pada pemendikbud 111 pasal 1 dan 3 (Kemendikbud, 2014). Pasal 1 berisi mengenai kualifikasi guru BK yang Profesional. Hal ini berarti walaupun perbandingannya tidak tidak sesuai, guru BK tetap melaksanakan layanan pada empat bidang secara professional. Salah satu dari bidang yang harus dikerjakan sebagai ciri professional adalah manajemen data. Data termasuk bagian yang sangat penting dalam proses layanan BK, terkadang dalam pengelolaan data kurang begitu baik dan juga cenderung masih diabaikan, namun ada juga sekolah yang mengelola data dengan baik oleh guru BK. Mengelola data dengan baik sama halnya menjaga system manajemen tersebut, yang bertujuan meningkatkan, dan memantapkan program BK secara menyeluruh dengan cara prefesional guru BK, semua itu saling keterkaitan dengan semua pihak atau steakholder (Yuwono \& Asni, 2017: 54). 
Berdasarkan studi perndahuluan yang dilaksanakan di Sekolah MTs NU TBS Kudus mengenai manajemen BK guru BK sudah memiliki jam di dalam masuk kelas bagi Program Bimbingan dan Konseling walau dirasakan belum begitu maksimalnya dalam pelaksanaan jam layanan tersebut.

\section{B. Metode}

Jenis penelitian ini menggunakan pendekatan penelitian kualitatif yang bersifat deskriptif. Penelitian kualitatif adalah penelitian yang menghasilkan data deskriptif berupa kata-kata tertulis atau lisan dari orang-orang dan perilaku yang diamati, pendekatan ini diarahkan pada latar belakang individu secara holistic dan utuh (Moleong, 2001: 201). Penelitian kualitatif lebih bersifat deskriptif yaitu data yang terkumpul berbentuk kata atau gambar, tidak mementingkan angka, tetapi lebih pada proses (Sugiyono, 2016: 109).

Sumber data berasal dari subjek dari mana data itu diperoleh. Subjek penelitian adalah tempat dimana data itu diperoleh. Objek penelitian adalah topik permasalahan yang dikaji dalam penelitian, dalam hal ini Manajemen BK meliputi Perencanaan, pengorganisasian, pelaksanaan dan pengontrolan. Adapun subjek dalam penelitian ini meliputi anggota struktural Bimbingan konseling sekolah madrsah TBS Kudus dan juga subjek pendukung tiga guru wali kelas dan juga enam siswa TBS Kudus. Adapun Teknik analisis data yang digunakan dalam penelitian ini adalah analisis deskriptif di lapangan model Miles and Huberman, yaitu: Data Reduction (Reduksi Data), Data Display (penyajian Data), Verification (Penarikan Kesimpulan) (Sugiyono, 2016: 110).

\section{Pembahasan}

\section{Bimbingan dan Konseling}

Bimbingan dan konseling sering dimaknai secara tidak tepat oleh sebagian orang bahkan oleh seorang praktisi sekalipun, bimbingan disatu sisi dan konseling disisi lain. Keduanya dijadikan dalam satu istilah, yaitu konseling. Dikarenakan integral kerja konselor meliputi pendekatan, teknik, langkah-langkah, sarana dan prasarana yang dipergunakan untuk membantu konseli, merupakan pekerjaan konseling. (Prayitno, 2015) konseling sebagai salah satu teknik didalam pelayanan bimbingan dari beberapa teknik lainnya. Bimbingan mencakup lebih luas dan konseling sebagai alat yang sangat penting dalam proses pelayanan bimbingan.

Bimbingan ialah suatu proses bantuan yang diberikan kepada individu maupun kelompok secara berkelanjutan dan sistematis oleh seorang ahli agar menjadi pribadi yang mandiri (Sukardi, 2002: 98). Sedangkan konseling ialah 
hubungan tatap muka secara rahasia, penuh dengan sikap penerimaan dan pemberian kesempatan dari seorang ahli yaitu konselor kepada konseli, konselor menggunakan pengetahuannya dan keterampilannya untuk membantu konseli agar dapat menuntaskan problem-problem di diri konseli (Nurihsan \& Yusuf, 2010: 120).

Dari yang dikemukakan diatas, dapat dimaksudkan bahwasannya dengan manajemen bimbingan dan konseling yaitu sebuah proses perencanaan, pengorganisasian, pengarahan, dan pengendalian dalam hal bimbingan dan konseling guna mencapai tujuan pendidikan yang diharapkan dan disepakati sebelumnya secara efektif dan efisien.

Terwujudnya pelayanan bimbingan dan konseling tidak lepas dengan sistem manajemen yang baik yang dimana diharapkannya dapat mengefektifkan dan mengefisienkan pelaksanaan kegiatan bimbingan konseling disekolah maupun madrasah. Sesuai dengan pendapat Juntika bahwasannya program layanan bimbingan dan konseling tidak akan terwujud, tercapai, terselenggara bila tidak adanya sistem manajemen yang bermutu dan terkonsep, yang dimana dilaksanakan secara sistematis, dan terarah dengan baik (A. J. Nurihsan, 2012: 203).

Secara etimologis, istilah konseling bermula dari Bahasa Latin, yakni consilium yang yang memiliki arti "dengan atau bersama" yang disusun dengan "menerima atau memahami". Namun dalam Bahasa Anglo-Saxon, ialah konseling bermula dari sellan yang bermakna "menyerahkan atau menyampaikan". Maka dari itu konseling ialah sebuah proses pelayanan bantuan yang dilakukan melalui interview konseling dari seorang ahli yang bermuara pada penyelesaian problem yang dihadapi oleh konseli (Prayitno, 2004: 123). Pengertian konseling menurut beberapa ahli sebagai berikut:

a. J.P Chaplin mengemukakan dalam bukunya bahwa konseling yaitu sebuah nama yang mempunyai luas pemaknaannya beraneka ragam guna membantu orang lain agar mampu menyesuaikan diri sesuai dengan prosedur; seperti, nasihat, diskusi terapeutis, pengadministrasian dan penafsiran tes, serta bantuan kejuruan (Chaplin, 2017: 218).

b. Farid mengemukakan makna konseling yaitu proses pemberian bantuan dengan cara interview konseling yang dilakukan oleh ahlinya (konselor) dengan individu yang sedang bermasalah (konseli). Seehingga maslah yang dihadapi dapat terselesaikan (Mashudi, 2011: 47).

c. Milton E. Hahn mengungkapkan didalam buku Sofyan bahwa konseling merupakan suatu proses interaksi antara individu dengan individu meliputi 
individu yang mempunyai problem (konseli) dengan individu yang professional (konselor) yang telah memiliki pengalaman untuk membantu seorang konseli dalam memecahkan problem yang dihadapinya (Willis, 2007: 136).

d. Menurut Agus Sukirno konseling yaitu seorang ahli (konselor) dalam proses pemberian bantuan secara face to face terhadap seorang konseli yang memilki problem untuk membantu dalam menuntaskan problem yang dihadapinya (Sukirno, 2014: 128).

Beberapa pendapat diatas menurut para ahli penulis memberikan kesimpulan bahwasannya konseling ialah upaya dalam pemberian bantuan yang dilakukan oleh Konselor (guru BK) kepada siswa yang memilki problem dengan melalui wawancara konseling sesuai dengan norma-norma yang berlaku supaya dapat teratasi. Maka dari itu dapat disimpulkan bahwa bimbingan dan konseling adalah proses pemberian layanan bantuan secara sistematis yang dilakukan oleh konselor atau guru BK untu mengembangkan pribadi, sosial, belajar, dan jenjang karir untuk masa depannya dengan melalui jenis-jenis layanan berdasarkan norma-norma yang berlaku sehingga individu atau kelompok dapat berkembang dan mandiri secara optimal.

Konseling merupakan sebuah layanan prefesional banyak dikenal sebagai penggunaan dalam ranah dunia pendidikan dikarenakan permulaan perkembangan konseling, di Indonesia pula konseling berakar dari dunia pendidikan. Konseling merupak termasuk keterkaitan dalam membantu, yang dimana suatu teknik untuk intervensi, untuk mengubah tingkah laku (Lesmana, 2012: 84).

\section{Manajemen Bimbingan dan Konseling}

Secara linguistik manajemen memeliki beberapa makna, menyesuaikan konteks dan yang dimaksudkannya, Term manajemen berasal dari bahasa inggris "manajemen" dengan kata kerja "to manage" yang artinya mengemudikan, mengarahkan, mengendalikan, menangani, mengelola, menyelenggarakan, menjalankan, mengatur, melaksanakan, memimpin, mengurus atau kemampuan menjalankan dan mengontrol. Manajemen adalah ilmu mengatur proses pemanfaatan sumber daya manusia secara efektif, yang didukung oleh sumbersumber lainnya dalam suatu organisasi yang mencapai tujuan tertentu (Sodik, 2017: 208). Pengertian manajemen menurut beberapa ahli, diantaranya:

a. Menurtu The Liang Gie, bahwasaannya manajemen ialah segenap proses penyelenggaraan dalam setiap usaha kerjasama sekelompok manusia untuk 
mencapai tujuan tertentu yang sudah direncanakan sebelumnya. (Gie, 2000: 79).

b. Mulyani A. Nurhadi dalam Suharsimi (2019: 206) mengemukakan bahwa manajemen adalah suatu kegiatan atau rangkaian kegiatan yang berproses pengelolaan kerjasama antar kelompok manusia yang tergabung dalam organisasi, guna mencapai tujuan yang sudah ditetapkan secara efektif dan efisinsi.

c. Abror Sodik (2017: 209) mengemukakan pendapatnya mengenai manajeman, yaitu proses yang dilakukan oleh individu maupun kelompok yang meliputi kegiatan perencanaan, prngorganisasian, pengarahan, dan pengawasan seluruh anggota organisasi serta menggunakan seluruh SDM yang ada untuk mencapai tujuan organisasi tersebut.

d. Sujana (2004: 60) mengemukakan bahwa manajemen adalah sebagai kemampuan dan keterampilan khusus untuk melakukan suatu kegiatan, baik bersama orang lain maupun melalui orang lain dalam mencapai tujuan organisasi.

Dari pendapat para ahli diatas dapat disimpulkan mengenai manajeman ialah sebuah proses pengelolaan dalam rangkaian kegiatan didalam organisasi meliputi perencanaan, pengorganisasian, pengarahan, pengendalian, kepada seluruh anggota organisasi dengan SDM yang ada untuk mencapai tujuan organisasi tersebut. Dalam hal ini diselaraskan oleh penulis, bahwasannya manajemen merupakan proses perencanaan, pengorganisasian, pengarahaan, dan pengendalian di dalam program bimbingan dan konseling.

Manajemen Bimbingan dan Konseling dalam Permendikbud Nomor 111 Tahun 2014 pada pasal 1 dijelaskan layanan Bimbingan konseling pada satuan pendidikan dilakukan oleh tenaga pendidik professional yaitu konselor atau Guru Bimbingan Konseling. Konselor adalah pendidik professional yang berkualifikasi akademik minimal Sarjana Strata Satu (S-1) dalam bidang bimbingan konseling dan memiliki kompetensi di bidang Bimbingan Konseling. (Kemendikbud, 2014) Sarjana Strata Satu (S-1) dalam bidang bimbingan Konseling dihasilkan dari Lembaga Pendidikan Tenaga Kependidikan (LPTK) serta dapat ditugaskan sebagai Guru BK untuk menyelenggarakan layanan BK pada satuan pendidikan disekolah.

Dalam proses manajemen tak lepas dengan fungsi-fungsi pokok yang menggambarkan saling berhubungan langkah-langkah tersebut, sesuai dengan yang dikemukakan oleh Prayitno (2004: 204) yaitu: prencanaan (planning), pengorganisasian (organizing), pelaksanaan (actuating) dan pengontrolan (controlling), lebih mudahnya disebut POAC. Hasiabuan dalam Asep (2016: 36) 
mengemukakan bahwa manajemen ilmu dan sei mengondisikan tahapan-tahapan pemanfaatan sumber daya manusia dan sumber daya lainnya sehingga efektif dan efisien guna mencapai tujuan tertentu. Sebab itu, manajemen diartikan sebagai proses perencanaan, mengorganisasi, pelaksanaan, dan pengontrolan dalam organisasi dengan segala aspeknya, manajemen yang baik terhadap pelayanan BK diharapkan tercapai dengan efektif dan efisien dalam penyelenggaraan bimbingan konseling disekolah.

Manajemen merupakan suatu kegiatan atau rangkaian kegiatan yang diorganisasikan oleh sekelompok orang, Manajemen adalah suatu kegiatan atau rangkaian kegiatan yang mengatur organisasi dalam proses pengelolaan usaha kerjasama sekelompok manusia, untuk mencapai tujuan organisasi, lembaga atau sekolah agar tercapai secara efektif dan efisien. Di dalam penerapannya manajemen yang baik harus ada beberapa prinsip yang dapat mendukung keberhasilan yang optimal, seperti: perencanaan yang matang, pelaksanaan yang tepat, dan juga dari pengontrolan atau pengawasan yg ketat.

Proses program bimbingan dan konseling disekolah memiliki fungsi-fungsi manajemen dalam tahapan-tahapan yang dimana diawali dengan perencanaan, pengorganisasian, pelaksanaan, dan pengevaluasian oleh guru BK. Asep (2016: 64) menyatakan dalam tahapan-tahapan perencanaan bimbingan konseling, yaitu: 1) melakukan analisis kebutuhan baik berupa aspek masalah dan kemudahan serta perkembangannya, 2) merumuskan tujuan dan sasaran yang menjadi perencanaan, 3) kebijakan dan prioritas sebagai analisa kebutuhan, 4) menyusun program kegiatan yang menjadi komponen opersional dari perencanaan, 5) menempatkan sumber daya dengan cermat, logis dan akurat, 6) menjabarkan rencana tersebut pada penerapannya, 7) evaluasi dan perbaikan. Santoadi (2010: 73) mengemukakan bahwa perencanaan program bimbingan dan konseling meliputi: 1) mengidentifikasi kebutuhan, 2) menganalisis situasi, 3) merumuskan dan mengoreksi pemecahan masalah yang dialami. Nurihsan (2012: 98) berpendapat aspek dalam perencanaan, yaitu: a) analisis kebutuhan dan masalah siswa, b) menentukan yujuan program, c) analisis situasi dan kondisi sekolah, d) menentukan jenis kegiatan, e) menentukan metode dan teknik, f) menetapkan personel, g) menetapkan fasilitas dan biaya, h) memperkirakan hambatan dan usaha penyelesaiannya.

Sedangkan organisasi adalah merupakan penetapan sumber daya manusia yang melibatkan suatu unit yang terstruktur terdiri dari kumpulan beberapa orang, yang berfungsi untuk mencapai tujuan tertentu. Sudjana (2004) mengemukakan bahwasannya pengorganisasian yaitu upaya mengintegrasikan sumber daya manusia dan non-manusia yang dibutuhkan, kedalam satu kesatuan 
sebagaimana yang telah direncanakan sesuai tujuan yang diharapkan. Abror Sodik (2017: 98) dalam bukunya mengemukakan bahwa pengorganisasian tindakan yang mengusahakan hubungan-hubungan kelakuan yang efektif perkumpulan orang bekerja sama secara efisien guna mencapai tujuan dan sasaran yang diharapkan.

Sukardi (2008: 124) berpendapat bahwa seorang konselor harus memperhatikan hal-hal dalm organisasi, meliputi: a) semua pihak yang berada dalam sekolah harus dihimpun dalam satu wadah sehingga terwujudnya sutu kesatuan dalam proses layanan bimbingan konseling, b) menyamakan persepsi dalam proses layanan, yaitu mekanisme kerja, pola kerja, prosedur kerja, c) adanya perincian tupoksi masing-masing, tanggung jawab dan juga wewenang.

Sebuah organisasi termasuk kunci dari manajemen bimbingan dan konseling dikarenakan setiap proses kegiatan manajemen bimbingan dan konseling mulai dari perencanaan hingga evaluasi memerlukan kekompakan koordinasi yang harmonis dan korelasi kerjasama dari semua lini baik konselor dan personel sekolah. Depdiknas (2008) yang menyatakan bahwasannya personel utama dalam proses pelaksanaan bimbingan dan konseling ialah konselor dan staff administrasi bimbingan dan konseling. Personil pendukung yang terkait dalam proses layanan bimbingan dan konseling dalam pendidikan yaitu kepala sekolah, wakil kepala sekolah, wali kelas, guru mata pelajaran, dan staf adminitrasi.

Pelaksanaan layanan bimbingan dan konseling termasuk hal yang sangat penting di dalam lini pendidikan. Oleh karena itu, program harus dilakukan seutuhnya sesuai dengan SKB Mendukbud Nomor 0433/P/1993 menyatakan bahwa: pelaksanaan bimbingan dan konseling adalah melaksanakan fungsi pemahaman, pencegahan, pengentasan, pemeliharaan, dan pengembangan dalam bidang bimbingan pribadi, bimbingan sosial, bimbingan belajar, dan bimbingan karier. Sukardi (2008: 125) mengemukakan pelaksanaan adalah kegiatan pelayanan bimbingan dan konseling yang berkaitan dengan seorang konseli.

Aqib (2013: 183) dalam proses layanan bimbingan konseling meliputi layanan orientasi, informasi, penempatan dan penyaluran, bimbingan belajar konseling individual, konseling kelompok, bimbingan kelompok. Dalam kegiatan pendukung meliputi instrumentasi bimbingan konseling, data, konferensi kasus, home visit, dan alih tangan kasus. Sesuai dengan Permendiknas Nomor 39 Tahun 2009 Pasal 1 ayat 6 bahwasannya dalam proses pelaksanaan bimbingan konseling yaitu guru BK sebagai personil utama mempunyai jam mengajar. Strategi dalam pelaksanaan program layanan sesuai dengan Depdiknas (2008) diperjelaskan sebagai berikut, pelayanan dasar : bimbingan klasikal, layanan orientasi, informasi, 
bimbingan kelompok, layanan pengumpulan data. Layanan responsif: konseling indivisual dan kelompok, alih tangan kasus, kolaborasi dengan guru wali kelas dan guru mata pelajaran, kolaborasi dengan wali siswa/ orang tua, kolabora dengan pihak-pihak diluar sekolah, bimbingan sebaya, konferensi kasus, home visit.

Evaluasi merupakan fungsi manajemen yang terakhir dalam layanan bimbingan konseling yaitu suatu kegiatan yang dikendalikan mulai dari perencanaan, pengorganisasian, pelaksanaan. Evaluasi berkaitan dengan mengawasi dan mensupervisi kegiatan yang sudah dikonsepkan dari awal, apakah program bimbingan konseling sudah sesuai dengan konsep program yang sudah dicanangkan. Santoadi (2010: 96) menyatakan pengendalian adalah upaya untuk menjamin agar unit kerja organisasi yang sesungguhnya sesuai dengan proses yang direncanakan. Mashudi (2011: 94) melanjutkan bahwasannya evaluasi program bimbingan dan konseling ialah suatu usaha untuk menilai efisiensi dan efektivitas pelayanan bimbingan dan konseling demi meningkatkan mutu program layanan bimbingan konseling.

Bimbingan adalah merupakan proses pemberian bantuan yang dilakukan oleh seorang ahli kepada individu baik anak-anak, remaja maupun dewasa dengan melalui usahanya sendiri untuk menemukan dan mengembangkan kemapuannya agar memperoleh kebahagian pribadi dan kemanfaatan social berdasarkan normanorma yang berlaku. Bimbingan lebih dominan diberikan untuk mengatasi kesulitan yang dihadapi oleh individu dalam kehidupannya. Dalam hal ini, bimbingan lebih bersifat pencegahan daripada penyembuhan, Karena bimbingan dimaksudkan agar individu atau sekumpulan individu mencapai kesejahteraan dan kebahagiaan hidup. Disinilah letak bimbingan yang sebenarnya.

Konseling adalah bantuan yang diberikan kepada siswa (konseli/klien) dalam membantu mengarahkan memecahkan masalah kehidupan, dengan wawancara secara face to face atau melihat keadaan dalam pelaksanaan konseling. Dengan demikian, bimbigan dan konseling yaitu sebagai suatu bantuan yang diberikan seorang ahli (konselor) kepada klien (konseli) untuk mengembangkan potensi atau memecahkan permasalahan yang sendang dihadapinya.

Manajemen BK sebagai suatu tahapan yang terdiri dari beberapa unsur mulai dari perencanaan, mengorganisasi, pelaksanaan, dan pengontrolan. Manajemen BK di sekolah berperan sangat penting terhadap keberhasilan kegiatan pelaksanaan BK secara menyeluruh, dengan manajemen yang professional, maka akan mampu memenuhi tuntutan BK sebagai peduli siswa. Oleh karena itu manajemen tidak hanya dibutuhkan pada sebuah lembaga yang bersifat bisnis saja, akan tetapi semua lembaga membutuhkan manajemen, termasuk juga pada 
lembaga yang saat ini menjadi objek penelitian, yakni Madrasah TBS Kudus. Didalam madrasah tersebut memiliki program BK yang dirancang untuk memenuhi kebutuhan siswa.

Agar tercapainya sebuah tujuan yang direncanakan sejak awal maka sangat diperlukannya manajemen yang tepat dan berkualitas. Madrasah TBS Kudus menjalankan manajemen program BK agar layanan yang diberikan dapat memenuhi semua kebutuhan siswa. Manajemen yang berkualitas tidak lepas dari guru BK dan semua pihak atau steakholder yang berkaitan dapat mencapai tujuan yang benar-benar efektif dan efisien.

\section{Implementasi Manajemen Bimbingan dan Konseling di MTs NU TBS Kudus}

a. Tahap Perencanaan

Tahap perencanaan BK di MTs NU TBS Kudus berjalan sudah cukup baik, ditandai dengan adanya analisis kebutuhan dan masalah siswa, analisis kondisi sekolah, penentuan tujuan, memahami dan menentukan materi, penentuan waktu dan tempat, penentuan fasilitas dan perencanaan anggaran, namun dalam hal pengelolaan anggaran biaya untuk kebutuhan bimbingan dan konseling di MTs NU TBS Kudus tidak dikelola oleh para konselor. Apabila konselor memerlukan anggaran, konselor perlu membuat proposal yang akan diberikan pada bagian keuangan sekolah.

Bimbingan Konseling MTs NU TBS sudah menerapkan jam masuk kelas satu jam perminggu, sesuai jadwal yang sudah ditentukan oleh pihak Waka Kurikulum. Dengan dasaran pada Permendikbud 111 Tahun 2014 diharuskan adanya tatap muka, namun dikarenakan menyesuaikan dengan kurikulum madrasah dan salaf/lokal maka madrasah baru dapat menyusun jadwal satu jam perminggunya setiap kelas, dengan diberlakukannya jam BK sangat disyukuri oleh Tim BK MTs NU TBS dikarenakan telah terjadi pmerataan dalam program kegiatan BK masuk kelas sehingga menjadi relative lebih mudah dalam pelaksanaan program BK, akan tetapi bagi guru BK waktu satu jam (45 menit) tidak cukup jika melaksnakan satuan layanan, sehingga layanan menjadi maksimal dan adapun layanan yang tidak dipergunakan dikarenakan keterbatasan waktu.

b. Tahap Pengorganisasian

Tahap pengorganisasian dalam manajemen BK di MTs NU TBS Kudus sudah terorganisir dengan cukup baik, hal tersebut ditandai dengan adanya 
alokasi jam dalam pembelajaran satu minggu sekali, dan dalam proses pengorganisasian tetap melaksanakan tugas seperti memilih konselor yang kompeten, menjalankan sosialisasi dan pembagian tugas antar petugas BK, dan koordinasi serta membangun kerjasama. Namun, betapa besarnya pengaruh BK belum diimbangi oleh konselor yang benar-benar ahli dalam bidang BK, karena hanya tiga dari tujuh konselor yang memang berasa dari Sarjana (S1) Bimbingan dan Konseling. Disamping itu, rasio tanggung jawab konselor juga tidak sesuai dengan aturan pemerintah yang tertuang di PERMENDIKNAS no. 111 tahun 2014 pasal 10 yang menjelaskan tentang rasio seorang konselor hanya menangani 150 siswa, sedangkan seorang konselor di MTs NU TBS Kudus menangani lebih dari 150 siswa.

Kegiatan sosialisasi dalam pengorganisasian dan pembagian kerja yang dilakukan BK sudah baik. Namun sebagian siswa masih menganggap BK adalah sosok yang disegani dan ditakuti, serta siswa juga mengganggap bahwa BK adalah polisi sekolah yang hanya menangani siswa-siswa yang bermasalah. Meski sosialisasi terkesan sudah berjalan dengan baik, peran BK di MTs NU TBS Kudus masih perlu dioptimalkan kembali agar tugas BK bukan hanya menangani siswa-siswa yang bermasalah saja, namun tugas BK menangani dan mengatasi problem semua siswa-siswa yang berada dalam lingkungan madrasah, baik itu masalah pribadi, keluarga, teman, dll.

Koordinasi dan membangun kerjasama dengan semua pihak baik dari dalam maupun dari luar sekolah dilaksanakan dengan baik oleh Manajemen Bimbingan dan Konseling MTs NU TBS Kudus, sebagaimana pengakuan Waka Kesiswaan, Waka Kurikulum, Waka Humas, Koordinator Bimbingan dan Konseling, petugas konselor, dan KA TU.

c. Tahap Pelaksanaan

Pelaksanaan bimbingan dan konseling MTs NU TBS Kudus berjalan sebagaimana perencanaan program yang dibuat. Hal tersebut ditandai dengan implementasi pelaksanaan layanan bimbingan dan konseling yang telah dilakukan oleh manajemen BK MTs NU TBS Kudus seperti layanan konseling, dan kegiatan pendukung. Untuk layanan konseling sejauh ini sudah dilaksanakan dengan baik sesuai garis besar pelaksanaan BK. Konselor bimbingan dan Konseling membuat beberapa catatan yang kemudian akan diimplementasikan dalam beberapa hal seperti catatan administrasi, laporan tahunan, laporan semesteran, laporan bulanan, slide presentasi layanan informasi dan orientasi, dan dokumen file yang terkait administrasi BK. 
d. Tahap Evaluasi (penilaian)

Kegiatan evaluasi (Penilaian) bimbingan dan konseling MTs NU TBS Kudus dimulai dari pembuatan laporan, Menurut data hasil penelitian, diketahui setiap selesai pemberian layanan, maka Konselor langsung membuat laporan bimbingan dan konseling. Dalam laporan BK ditulis adanya evaluasi kegiatan BK yang berupa evaluasi secara proses dan hasil selain itu juga ditulis adanya kegiatan tindak lanjut setelah melaksanakan kegiatan BK tersebut. Hal ini menyatakan bahwa adanya penilaian konselor dari pelaksanaan kegiatan BK.

Penilaian hasil kerja BK MTs NU TBS Kudus dilakukan secara intern dan ekstern. Penilaian intern dilakukan oleh auditor dari personel MTs NU TBS Kudus sendiri, sedangkan untuk kegiatan penilaian ekstern dilakukan menurut pengakuan Koordinator Bimbingan dan Konseling selama ini belum dilakukan oleh pihak dinas pendidikan terkait.

e. Faktor Penghambat Dan Pendukung Implementasi Layanan BK

Guru BK (koselor) di MTs NU TBS Kudus sudah melaksanakan tahapan manajemen dalam bimbingan dan konseling dan sudah berupaya memberikan layanan terbaik bagi siswa sesuai dengan kondisi dan situasi sekolah, kompetensi yang dimiliki petugas BK, tetapi dalam melaksanakan program tersebut mungkin ada kekurangan. Hal tersebut dibuktikan belum bisanya Koordinator BK menunjukkan efektifitasnya BK, karena pada saat penelitian berlangsung koordinator BK kesulitan mencari arsip sebagai bukti laporan evaluasi karena kantor Bimbingan dan Konseling sedang dindah di lokasi baru.

Pelaksanaan fungsi manajemen bimbingan dan konseling di MTs NU TBS Kudus memperlihatkan bahwa faktor pendukung kegiatan bimbingan dan konseling adalah tersedianya fasilitas MTs NU TBS Kudus yang memadai dalam keadaan baik dengan jumlah memadai, koordinasi dan hubungan baik anatara pihak konselor dan pemangku kebijakan di sekolah, sumber daya sebagai konselor yang professional dan memiliki pengalaman lapangan menghadapi berbagai permasalah siswa.

Manajemen bimbingan dan konseling di MTs NU TBS Kudus masih menghadapi berbagai permasalahan dan kendala dalam manajemen bimbingan dan konseling terkait dengan kondisi dan situasi sekolah yaitu mengenai tanggung jawab seorang konselor terhadap siswa yang melebihi batas maksimal, kurang solidnya dalam mengatasi masalah kedisiplinan 
siswa, sehingga hal tersebut dapat mempengaruhi kualitas layanan Bimbingan Konseling itu sendiri.

Adapun faktor penghambat kegiatan bimbingan dan konseling di MTs NU TBS Kudus adalah masih belum optimal guru BK dalam mengimplementasikan ilmunya, belum optimalnya sosialisasi dan komunikasi tentang fungsi dan cara tugas BK kepada rekan, siswa dan orang tua.

Tahap perencanaan program bimbingan dan konseling di MTs NU TBS Kudus berjalan baik yang dimana terlihat adanya program BK mengenai kegiatan analisis kebutuhan siswa, analisis situasi dan kondisi sekolah, penetapan tujuan, jenis layanan, waktu kegiatan, dan penyediaan angket yang dibutuhkan, namun sarana prasarana atau fasilitas ruang BK belum cukup memadai dikarenakan belum adanya ruang tertutup atau ruang kedap suara. Hanya saja terdapat ruang layanan tanpa adanya penutup, namun itu semua tidak menghalangi proses pelaksanaan program BK.

Tahap pengorganisasian dalam manajemen program BK MTs NU TBS Kudus sudah berjalan dengan baik, dilihat dari pembagian tugas dan terpelibatan steakholder dalam kegiatan BK, meskipun sosialisasi tidak dilakukan secara diagendakan, serta korelasi antar steakholder kurang terjaga,dikarenakan komunikasi terjalin ketika adanya penanganan masalah. Maka dari itu disarankan pada para guru BK agar mensosialisasikan mengenai kinerja dan program BK secara rutin dan merata ke semua pihak.

Tahap pelaksanaan program BK di MTs NU TBS Kudus bisa disimpulkan bahwa berjalannya belum optimal dan merata di semua tingkatan kelas, karena jam masuk kelas satu jam perminggu hanya diperuntukan dikelas 7 dan kelas 9, kelas 8 masih belum adanya jam BK yang terjadwal seperti kelas 7 dan 9. Dan juga disarankan kepada pihak guru BK dapat memotivasi diri dalam mengaplikasikan keilmuwannya dalam pengembangan program pelaksanaan BK, dan tak luput juga kepada kepala Madrasah supaya memberikan ketegasan kepada pihak guru BK agar memanfaatkan jadwal khusus BK dimanfaatkan dengan sebaik mungkin, dan guru BK bisa mengoptimalkan dengan sebaik mungkin.

Tahap evaluasi program BK di MTs NU TBS Kudus bisa disimpulkan bahwa dengan berjalannya belum optimal ditandai dengan kurangnya ketegasan dan juga kedisiplinan dalam mengkondisikan dan penilaian terhadap anggotanya, serta kurang sigapnya koordinator BK untuk 
mengevaluasi program-program untuk diperbaiki kembali. Petugas / guru BK-pun harus lebih bisa mengimplementasikan yang didapatkannya dari pelatihan ataupun seminar dalam kehidupan pendidikan agar program BK dapat berjalan dengan sesuai yang diharapkan.

\section{Simpulan}

Dari beberapa uraian sebelumnya dapat dikemukakan hal-hal berikut ini: Pertama tahap perencanaan program bimbingan dan konseling di MTs NU TBS Kudus berjalan sudah cukup baik, ditandai dengan adanya analisis kebutuhan dan masalah siswa, analisis kondisi sekolah, penentuan tujuan, memahami dan menentukan materi, penentuan waktu dan tempat, penentuan fasilitas dan perencanaan anggaran. Dalam hal pengelolaan anggaran biaya untuk kebutuhan bimbingan dan konseling

Kedua, tahap pengorganisasian dalam manajemen BK di MTs NU TBS Kudus sudah terorganisir dengan cukup baik, hal tersebut ditandai dengan adanya alokasi jam dalam pembelajaran satu minggu sekali, dan dalam proses pengorganisasian tetap melaksanakan tugas seperti memilih konselor yang kompeten, menjalankan sosialisasi dan pembagian tugas antar petugas BK, dan koordinasi serta membangun kerjasama. Namun, betapa besarnya pengaruh BK belum diimbangi

Ketiga, tahap pelaksanaan bimbingan dan konseling dalam penelitian ini dapat disimpulkan berjalan sebagaimana perencanaan program yang dibuat. Hal tersebut ditandai dengan implementasi pelaksanaan layanan bimbingan dan konseling yang telah dilakukan oleh manajemen BK MTs NU TBS Kudus seperti layanan konseling, dan kegiatan pendukung. Untuk layanan konseling sejauh ini sudah dilaksanakan dengan baik sesuai garis besar pelaksanaan BK.

Keempat, tahap evaluasi program BK di MTs NU TBS Kudus bisa disimpulkan bahwa belum terlaksana dengan optimal ditandai dengan kurangnya ketegasan dan juga kedisiplinan dalam mengkondisikan dan penilaian terhadap anggotanya, serta kurang sigapnya koordinator BK untuk mengevaluasi programprogram untuk diperbaiki kembali.

Kelima, faktor pendukung implementasi program bimbingan konseling di MTs TBS Kudus meliputi: 1) tersedianya ruang BK yang sudah dimiliki oleh MTs NU TBS, 2) dilibatkannya steakholder dalam kegiatan BK, 3. Dukungan madrasah terhadap organisasi BK untuk mengembangkan melalui pelatihan dan seminar. Sedangkan factor penghambat program bimbingan konseling di MTs TBS Kudus yakni: 1) masih minimnya guru BK yang berlatar belakang Bimbingan Konseling 
Implementasi Manajemen Bimbingan dan Konseling ...

atau S1 BK, 2) jam masuk kelas masih belum merata di setiap tingkatan, 3) belum tersedianya ruang Konseling yang kedap suara, 4) belum optimal guru BK dalam mengimplementasikan ilmunya, 5) dan belum optimalnya sosialisasi dan komunikasi tentang fungsi dan cara tugas BK kepada rekan, siswa dan orang tua. 


\section{DAFTAR PUSTAKA}

Aqib, Z. (2013). Ikshtisar Bimbingan dan Konseling di Sekolah. Bandung: Irama Widya.

Arikunto, S., \& Yuliana, L. (2019). Manajemen Pendidikan. Depok: Graha Cendekia.

Bastomi, H. (2017). Menuju Bimbingan Konseling Islami. KONSELING EDUKASI: Journal Of Guidance And Counseling, 1 No. 1. https://doi.org/10.21043/konseling.v1i1.4434

Bastomi, H. (2019). Konseling Cyber: Sebuah Model Konseling Pada Konteks Masyarakat Berbasis Online. Konseling Edukasi: Journal of Guidance and Counselling, 3, No. 1.

Bastomi, H. (2020). Pemetaan Masalah Belajar Siswa SMK Negeri 3 Yogyakarta Dan Penyelesaiannya (Tinjauan Srata Kelas). KONSELING EDUKASI: Journal Of Guidance And Counseling, 4 No. 1.

Chaplin, J. . (2017). Kamus Lengkap Psikologi. Jakarta: Raja Grafindo Persada.

Depdiknas 2008 Permendiknas Nomor 27, Tahun 2008, mengenai Standar Kualifikasi Akademik dan Kompetensi Konselor.

Depdiknas, Permendiknas Tahun 2008, tentang Strategi dalam pelaksanaan program layanan

Gie, T. L. (2000). Administrasi Perkantoran Modern. Yogyakarta: Liberty.

Lesmana, J. M. (2012). Dasar-dasar Konseling. Jakarta: UI Press.

Mashudi, F. (2011). Psikologi Konseling. Sumenep: IRCiSoD.

Moleong, L. J. (2001). Metodologi Penelitian Kualitatif. Bandung: Remaja Rosdakarya.

Nurihsan, A. J. (2012). Strategi Layanan Bimbingan dan Konseling. Bandung: Refika Aditama.

Nurihsan, J., \& Yusuf, S. (2010). Landasan Bimbingan dan Konseling. Bandung: Remaja Rosdakarya.

Permendikbud Nomor 111 Tahun 2014. Bimbingan dan Konseling Pada Pendidikan Dasar dan Pendidikan Menengah. Jakarta: Kemdikbud.

Prayitno. (2004). Dasar-dasar Bimbingan dan Konseling Islam. Jakarta: Rineka Cipta.

Saepulrohim, A. (2016). Manajemen Bimbingan dan Konseling Islam. Bandung: 
Mimbar Pustaka.

Santoadi, F. (2010). Manajemen Bimbingan dan Konseling Komprehensif. Yogyakarta: Universitas Sanata Dharma.

Sodik, A. (2017). Manajemen Bimbingan Konseling. Yogyakarta: Aswaja Pressindo.

Sudjana. (2004). Manajemen Program Pendidikan untuk Pendidikan Nonformal Pengembangan Sumber Daya Manusia. Bandung: Falah.

Sugiyono. (2016). Metode Penelitian Kuantitatif, Kualitatif, dan R\& D. Bandung: Alfabeta.

Sukardi, D. K. (2002). Manajemen Bimbingan dan Konseling di Sekolah. Bandung: Alfabeta.

Sukardi, D. K. (2008). Pengantar Pelaksanaan Program Bimbingan dan Konseling di Sekolah. Jakarta: Rineka Cipta.

Sukirno, A. (2014). Bimbingan dan Konseling Islam. Sarang: A-Empat.

Willis, S. S. (2007). Konseling Individual Teori dan Praktek. Bandung: Alfabeta.

Yuwono, S. D., \& Asni. (2017). Evaluasi Program Bimbingan dan Konseling. Jakarta: UHAMKA. 